\title{
The Role of Mathematical Values Concept in the Internalization of Insan kamil
}

\author{
Nilatul Azizah",2, Ita Fitriyah'. \\ ${ }^{1}$ Islamic Boarding School of Jagad Alimussirry Surabaya, Indonesia \\ ${ }^{2}$ Program Mathematic, Universitas Negeri Surabaya, Indonesia
}

\begin{abstract}
The lack of knowledge and understanding of human beings to the values implied in mathematics that causes mathematics is considered as a lesson that is very contrary to the concept of religion, especially the field of Sufism when in fact mathematics is a means provided by Allah SWT to facilitate people to carry out the task of servitude and the task of the caliphate to the level of insan kamil. This research uses a qualitative approach. Literature review was used to obtain research data. The results of this study state that the concept of mathematical values in the internalization of insan kamil is to encourage humans to develop problem solving skills, communication skills, and reasoning skills to face every situation and problem in life. This discussion also presented that mathematics in addition to teaching to think and reason but also teach honest, humble, not arrogant, sincere, iffah, consistent and systematic attitude. This is a reflection of insan kamil.
\end{abstract}

Keywords: insan kamil; mathematics; internalization;

\section{INTRODUCTION}

Human beings are the best creatures (insan kamil) created by Allah SWT on the surface of nature. Insan kamil can be explained through characteristics: functioning his mind optimally, functioning his intuition, adorning himself with divine qualities (fitrah), and noble character (Kulsum, 2019). Man is the most intelligent being. This is in line with QS. 96: 1-5 is an order to read and learn as well as the hadith of the Prophet Muhammad SAW that gives an obligation that is to study to his people.

Islamic teachings command his people to study the universe as a way to draw closer to Allah SWT in order to achieve the happiness of the world and the here after. Here, Mathematics is the underlying science of development in various sectors so as to provide benefits and convenience for its users (Azizah \& Jakfar, 2021). However, the society's paradigma vigorously states that mathematics has nothing to do with religion it is an untrue statement.

Mathematics is a science that is inseparable from religion. This view can clearly be known from the verses of the Qur'an relating to mathematics. In QS. 51:56 and QS. 2:30 it is explained that man's duty is to do servitude and caliphate. Mathematics is nothing but a means provided by Allah SWT to facilitate people to carry out the task of servitude and the task of the caliphate (Abdussakir \& Rosimanidar, 2017). Mathematics is taught with the primary purpose of developing 
problem solving skills, communication skills, and reasoning skills to deal with every situation and problem in life. Another goal that is no less important is to develop an honest,humble, sincere, iffah, consistent and systematic attitude. So, it is all a concept of the values contained in mathematics. Learning mathematics is closely related to intuitive, imaginative, and metaphysical necessary to understand abstract aspects of mathematics. The main strength in mathematics lies precisely in imagination or intuition which is then accepted after being logically or deductively proven. Based on the description above can be known together that mathematics has a role to support the task of life of human beings kamil namely man as a servant of God ('abdullah) and caliph of Allah on earth (khalifatullah fil 'ardl) (Abdussakir, 2007).

This paper aims to discuss in depth the role of the concept of mathematical values in the internalization of human beings, how the concept of mathematical values in the internalization of human beings, the verses of the Qur'an related to the concept of mathematics, the urgency of knowing the role of the concept of values. mathematics in the internalization of human beings.

\section{METHOD}

This research uses a qualitative approach. Literature study method used to obtain research data, both primary and secondary. Primary data obtained from written sources directly discusses the concept of mathematical values that can be internalized in insan kamil, the book Matematika dalam Al-Qur'an, articles: Matematika Akhlak: Internalisasi sikap-sikap terpuji (Akhlak Mahmudah) dalam sistem bilangan melalui strategi analogi, Integrasi Nilai-nilai Islam dengan Materi Himpunan (Kajian terhadap Ayat-ayat Al-Qur'an), Insan kamil sebagai Idealitas Muslim, the book Amaliah Thariqot Jagad 'Alimusirry, and others. Meanwhile, secondary data were obtained from books discussing number systems, multiplication, sets, and algebra as well as scientific journals on the concept of mathematical values and national seminars. The first data collection method is finding data analysis.

In this study using descriptive analysis, starting with examining the available data, namely books, articles and seminar papers related to the concept of mathematics and insan kamil. The next step is content analysis, which is a method in which data is only analyzed according to its content (Suryabrata, 2008) by selecting data by analyzing, finding, and making connections between the two, namely the concept of mathematical values and insan kamil. Then use a deductive approach, using logic to draw one or more based on a given set of premises. In a complex deductive system, the researcher can draw more than one conclusion. The deductive method is often described as drawing conclusions going from the general to the specific (Rosimanidar, 2015). This method draws conclusions from the collection of relational data obtained to produce a more objective view of the role of mathematical values in the internalization of insan kamil. 


\section{RESULT AND DISCUSSION}

\section{A. The Role of Mathematical Values Concept in Internalization of Insan kamil}

Mathematical values have a big role in the internalization of human beings kamil. Mathematics is taught with the primary purpose of developing problem solving skills, communication skills, and reasoning skills to deal with every situation and problem in life.

Another goal that is no less important is to develop a love attitude of truth, honesty, spirit of learning, not arrogant, sincere, patient, responsibility, simple, fair, consistent, and systematic. All the commendable attributes that have been mentioned are concepts of values contained in mathematics. Learning mathematics is very closely related to the formation of akhlaqul karimah and with akhlaqul karimah it will be achieved internalization of human kamil. So, it can be said that the role of the concept of mathematical values in the internalization of insan kamil is very strong.

\section{B. Concept of Mathematical Values in Internalization of Insan kamil}

The perspective of Ibn 'Arabi and 'Abd Al-Karim Al-Jilli as Muslim idealities can be explained by the following characteristics:

\section{1) Functioning Sense Optimally}

According to Ibn Bajjah, reason is the most important part of man, because true knowledge can be obtained through reason (Supriyadi, 2009). This man who functions his mind optimally that can go to the level of human kamil.

This concept is in line with the etymological mathematical definition. The word math comes from the Greek mathema which means something to learn or something to know. Mathema is derived from the word manthano or equivalent to the word mathaino which means learning. The word form is mathematikos which means things related to learning or learning (Abdussakir, 2007). Nasoetion (1980) states that mathematics comes from the Greek mathein or manthenein which means to learn. Etymologically, mathematics can be interpreted as a science obtained by thinking.

The ability to think is systematic, logical, analytical, critical, and creative. Reasoning abilities developed for example are properly reasoned deductively, without forgetting inductive reasoning. Developing the potential of thinking and reasoning is highly recommended by the Qur'an. There are three terms used by the Qur'an to stimulate people to use their intellectual potential, namely afala tatafakkarun (do not think) as in QS. 6:50 and QS. 30:8, afala ta'qilun/ya'qilun (whether un reasoned) as in QS. 2:44, QS. 3:65, QS. 11:51, QS. 36:68, or QS. 37:138, and afala tadzakkarun (whether not learning) as in QS. 37:155.

Mathematics is a tool especially to help people understand and overcome problems in their lives. Mathematics is taught with the primary purpose of developing problem solving skills, communication skills, and reasoning skills to deal with every situation and problem in life. So, by learning mathematics we can think and reason to enable reason optimally. 


\section{2) Functioning Intuition}

In contrast to rational knowledge, intuitive recognition is called huduri because the object of research is present in the soul of its researcher, so that it becomes one and is identical to it (Irawan, 2014). Studying science including mathematics in Islam is done holistically through the utilization of the potential of dhikr and thinking by burhani, bayani, and 'irfani methods. Rationalist, empirical, and logical approaches (bayani and burhani) are necessary to understand the real aspects of mathematics. While an intuitive, imaginative, and metaphysical approach ('irfani) is necessary to understand the abstract aspects of mathematics. The main strength in mathematics lies precisely in imagination or intuition which is then accepted after being logically or deductively proven (Abdussakir, 2007).

\section{3) Decorate Yourself with Divine Attributes}

Human is a creature that has a divine instinct (fitrah). He tends to things that come from God, and believes in them. These attributes make him a representative of God on the earth. As God says in QS. Al-Baqarah: 30

In mathematical terms, a number called an original number is introduced. The original number is part of the number system. The number system consists of a set of original numbers, a set of numbers, a set of integers, a set of rational numbers, a set of real numbers, and a set of complex numbers (Gilbert \& Gilbert, 2009).

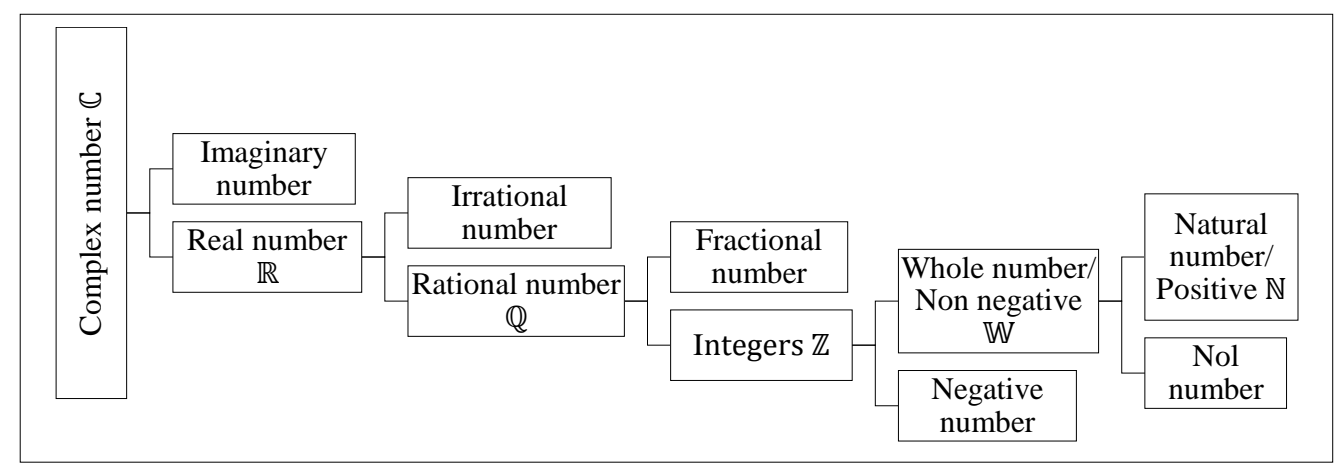

Figure 1. Number System Concept Map

\section{4) Noble Character}

Mathematical values in the internalization of noble morals include:

a) Tawadhu' (Humble) and Not Arrogant

Note $\mathbb{Q}$ is a fractional number $\frac{a}{b}$ consisting of an integer $a$ commonly referred to as a numerator and an integer $b$ where $b \neq 0$ it is called a denominator. This means there are no restrictions for numerators $a$. This means that the denominator $b$ of its value is limited to positive and negative numbers only.

From this explanation can be done analogy suppose $a$ analogous as God, Dzat which has an infinite nature, in general we consider that God is All-powerful. Furthermore, the denominator is analogous to being a limited human being, i.e. limited by space and time. Next look at the results of the following divisions $b$. 
Table 1. Dividend result

\begin{tabular}{|c|c|c|c|c|c|c|}
\hline \multicolumn{7}{|c|}{ Apply the value $b$, suppose $\mathrm{b}=2$} \\
\hline$\frac{1}{2}=0,5$ & $\frac{2}{2}=1$ & $\frac{3}{2}=1,5$ & $\frac{4}{2}=2$ & $\frac{10}{2}=5$ & $\frac{100}{2}=50$ & $\cdots$ \\
\hline \multicolumn{7}{|c|}{ Set the value to $a$, suppose $\mathrm{a}=2$} \\
\hline$\frac{2}{1}=2$ & $\frac{2}{2}=1$ & $\frac{2}{3}=0,67$ & $\frac{2}{4}=0,5$ & $\frac{2}{10}=0,2$ & $\frac{2}{100}=0,02$ & $\ldots$ \\
\hline
\end{tabular}

By setting the value of $b$ the more large numerator value $a$, the result is getting bigger. Then, by setting the value $a$, the greater the value of denominator $b$ then the smaller the result, and the smaller the denominator value $b$ then the greater the result.

Furthermore, by analogy of numerator $a$ as God and denominator $b$ as a human being, then obtained analogy from the sentence "the greater the value of the numerator, the greater the result" which means the more glorify God against Himself then really God shows that He is the Almighty. Then the analogy of the sentence "the greater the value of the denominator $b$ then the smaller the result, and the smaller the value of the denominator $b$ then the greater the result" is inappropriate for man to boast. If man is more proud of himself and feels himself more than others then his level is lower and worthless in the sight of Allah SWT. On the contrary, if man humbles himself not to feel more than others, then his degree before Allah SWT is higher. In this regard, Shaykh Az-Zarnuji (2004) advises us to avoid arrogance in a verse listed in the following Book of Ta'lîm al-Muta'allim:

Pride is a characteristic of our Lord, so stay away from it and be afraid of yourself.

Therefore, it is proper for mankind to always be tawadhu' (humble) and not to be proud. Because the arrogant nature is an absolute trait only has Allah SWT.

In $\mathbb{Z}$ also implied meaning to build a humble attitude that can be observed as follows. In writing there is a question $\mathbb{Z}=\{\ldots,-3,-2,-1,0,1,2,3, \ldots\}$, why not written $\mathbb{Z}=\{\ldots,-3,-2,-1,0,+1,+2,+3, \ldots\}$. Meaning that we can take from the number +3 is quite written 3 and so on that self-positivity does not need us to highlight to others. On the contrary we do not write -3 with 3 , this means self-negativity that we must remember to bring a sense of regret and repentance (Abdussakir, 2017). This is based on the hadith of the Prophet SAW that the signs of happiness there are 2 namely: always remembering the ugliness (negativity), and always forget the good (positivity) that we have done (Nawawi, 1994).

b) Sincere

Instilling a sincere attitude in mathematics learning can be done by analogizing giving and hope through the division of numbers 1 with other positive integers. Let's take a look at the following example:

$1:$ limit to infinity $=$ limit to zero

$1: 100=0,01$ 


$$
\begin{aligned}
& 1: 10=0,1 \\
& 1: 1=1 \\
& 1: 0,1=10 \\
& 1: 0,01=100 \\
& 1: 0,000000001=1000000000 \\
& 1: \text { limit to zero = limit to infinity. }
\end{aligned}
$$

Then this example can be analogized as an inductive analogy described in the form of division: hope $=$ result. This can be interpreted that the greater the expectation for a gift, the smaller the result. And on the contrary, the giving is increasingly not accompanied by the hope of retribution (sincere), then the result is increasingly towards the unanited (Abdussakir, 2017).

c) Honest

Handojo (2007) developed an honesty analogy through the nature of integer multiplication operations. That is the nature below.

(1) positive $\mathrm{x}$ positive $=$ positive

(3) positive $x$ negative $=$ negative

(2) negative $x$ positive $=$ negative

(4) negative $x$ negative $=$ positive developed into the conclusion of the following honesty analogy

(1) true if it is said to be true then the behavior is correct

(2) wrong if it is said to be true then the behavior is wrong

(3) right if it is said to be wrong then the behavior is wrong

(4) wrong if it is said wrong then the behavior is correct (Abdussakir, 2009).

For another example, in Pythagoras learning students are asked to measure the length of the oblique side with a ruler. Students who paint it inappropriately (lie) will not get the right answer. Then the message of honesty is also implied in the material of drawing a right triangle.

d) Iffah

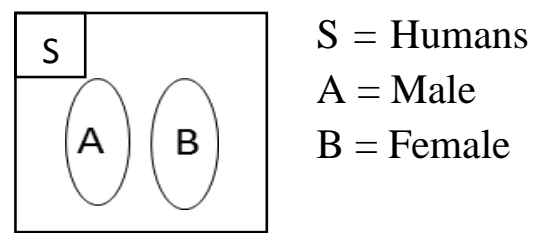

Figure 2. Venn Diagram of Humans

In the loose set there are values contained in it. That is by regretting that the male student association and the female student set are two examples of loose sets. So male and female students (who are not makhrom) should not go hand in hand with each other (Nihayati, 2017). Where in the Venn diagram that states the relationship of the two sets is a loose set is depicted with two simple closed curves made apart. Here it appears that the value of self-care / iffah has also been taught in mathematics. 
e) Simple and Fair

In the completion of Linear Equation of Two Variables the shape is complicated need to be simplified first form in order to be easily solved. This contains the message that a simple life will make it easier for us to solve life problems or life problems will be easier to solve if our lifestyle is simple.

In this material, it actually embeds fairness through the process of solving Linear Equation of Two Variables by means of both segments plus or minus the same number, multiplied or divided by the same number.

f) Consistent and Systematic Attitude to Rules

Mathematics is a science based on systematic agreements and from that agreement a person who works with mathematics must adhere to it. For example if in mathematics the number of angles in a triangle $=180^{\circ}$ in euclid geometry. Not only that, another example of the concept of numbers.

\section{Verses of the Qur'an Relating to the Concept of Mathematics}

\section{1) Length Measurement}

In QS. Al-Haqqah verse 32.

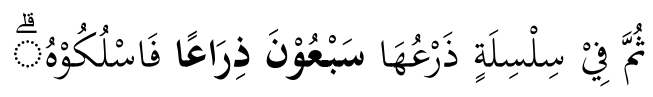

On QS. Al-Haqqah there is a traditional unit of length, namely cubit. The unit of measure of length used is a non-standard unit. Had the Qur'an been revealed in his time who already knew the unit of meter $(\mathrm{m})$, it might no longer be used the word two ends of the bow or seventy cubits. It could be used the word $50 \mathrm{~cm}$ or $75 \mathrm{~cm}$.

2) Time Measurement

In QS. Al-Ankabut verse 14

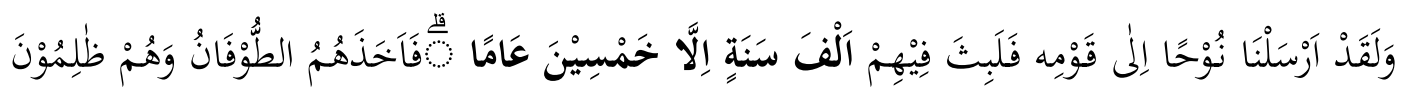

3) Area Measurement

In QS. Ali Imron verse 133

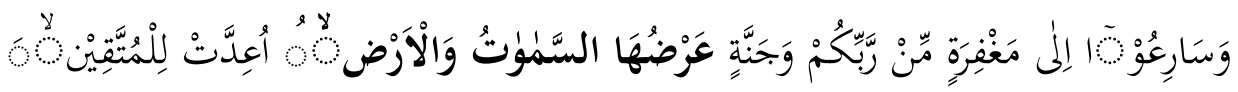

4) Weight Measurement

In QS. Luqman verse 16

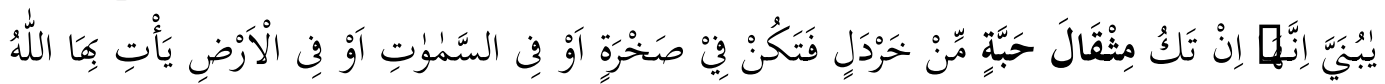

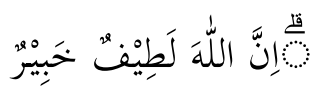


A unit of measure the weight of the habbah is a traditional non-standard unit. This is because at that time there were no standard units such as milligrams (mg), grams $(\mathrm{g})$, kilograms $(\mathrm{kg})$. However, it is clear that the Qur'an also talks about weight measurement.

5) Summing Operations

In QS. Al-Baqarah 196

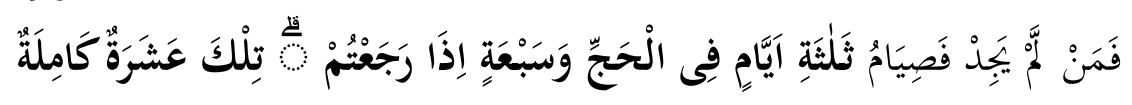

On QS. Al-Baqarah 196, it appears that 3 units in days and 7 also in units of days. Thus the summation of 3 and 7 can be done because the units are the same, i.e. the day. So obtained 3 days +7 days $=10$ days (Abdussakir, 2011).

\section{Urgency of the Role of Mathematical Values Concept in Internalization of Insan kamil}

The lack of knowledge and understanding of human beings to the values implied in mathematics that causes mathematics is considered as a lesson that is very contrary to the concept of religion, especially the field of Sufism when in fact mathematics is a means provided by Allah SWT to facilitate people to carry out the task of servitude and the task of the caliphate. Where man was created as a human kamil served as a caliph/ representative of God on the earth. In addition, the purpose created by man is to ma'rifatullah.

The role of the concept of mathematical values in the internalization of human beings kamil important to know so that the paradigm of society that states that mathematics has nothing to do with religion is not re-heard. In addition, by knowing the role of the concept of mathematical values in the internalization of human beings kamil we can apply it in the life of reality to go to the level of the real insan kamil.

\section{CONCLUSION}

The results of this study state that the concept of mathematical values in the internalization of insan kamil is to encourage humans to develop problem solving skills, communication skills, and reasoning skills to face every situation and problem in life this is in line with the command of the Qur'an اَفَلَ تَعْقِلْوْنَ (they should think). So, religion invites humans (sensible beings) to think. This discussion also presented that mathematics in addition to teaching to think and reason but also teach honest, humble, not arrogant, sincere, iffah, consistent and systematic attitude. so that we can apply it in real life to get to the real level of insan kamil. 
Nilatul, A. \& Ita, F., 2021

Journal Intellectual Sufism Research, 4(1)

\section{REFERENCES}

Abdussakir. (2007). Ketika Kyai Mengajar Matematika. Malang: UIN MALANG Press.

Suryabrata, S. (2008). Metodologi penelitian/sumadi suryabrata. Jakarta: Raja Grafindo Persada.

Abdussakir. (2009). Matematika 1: Kajian Integratif Matematika dan Al-Qur'an. . Malang: UIN Malang Press.

Abdussakir. (2011). Matematika dalam Al-Qur'an. Malang: UIN Malang Press.

Abdussakir. (2017). Internalisasi Nilai-Nilai Islami dalam Pembelajaran Matematika dengan Strategi Analogi. In Seminar Nasional Integrasi Matematika dan Nilai Islami (SI MaNIS). Malang: Jurusan Matematika FST UIN MALIKI.

Az-Zarnuji, B. al-I. (2004). Ta'lim Muta'allim 'ala Thariqi Ta'allum. Sudan: al-Dar al-Sudaniyah li alKutub.

Abdussakir, \& Rosimanidar. (2017). Model Integrasi Matematika dan Al-Qur'an serta Praktik Pembelajarannya. Makalah Seminar Nasional Integrasi Matematika di dalam Al-Qur'an Dengan Tema "Build a Competitive and Intellectual Young Mathematician Through Mathematics Competition and Integrating.

Azizah, N., \& Jakfar, M. (2021). Deinisi Sederhana dari Generalisasi Ruang Bernorma dan Sifat-sifatnya. MATHunesa Jurnal Ilmiah Matematika, 9(2).

Gilbert, L., \& Jimmie, G. (2009). Elements of Modern Algebra (Seventh ed.). USA: Gary Ostedt Brooks/Cole Thomson Learning.

Irawan, B. (2014, Januari-Juni). Intuisi Sebagai Sumber Pengetahuan: Tinjauan Terhadap Pandangan Filosof islam. Teologia, 25.

Kulsum, U. (2019). Insan kamil sebagai Idealitas Muslim (Perspektif Ibn 'Arabi dan 'Abd al-Karim al-Jilli. Tahil Al-'Ilmi, 11(1), 79-90.

Nawawi, M. (1994). Nashoihul 'Ibad. Surabaya: Daar an-Nasyr al-Misyiriyah.

Nihayati. (2017). Integrasi Nilai-nilai Islam dengan Materi Himpunan (Kajian terhadap Ayat-ayat alQur'an). Edumath, 3(1), 65-77.

Rosimanidar. (2015). Nilai-Nilai Akhlak yang Diinternalisasikan dalam Pembelajaran Aljabar SMP. Itqan, $4(2), 123-140$.

Supriyadi, D. (2009). Pengantar Filsafat Islam: Konsep, Filsuf, dan ajarannya. Bandung: Pustaka.

Suryabrata, S. (2008). Metodologi Penelitian. Jakarta: CV. Rajawali. 